\title{
PENGARUH KECERDASAN EMOSIONAL, KARAKTERISTIK PEKERJAAN DAN BEBAN KERJA TERHADAP KINERJA PEGAWAI DINAS PENDIDIKAN KOTA PADANGSIDIMPUAN
}

\author{
${ }^{1}$ Roni Mukti Siregar, ${ }^{2}$ Leonard Simorangkir, ${ }^{3}$ Satria Ginting, ${ }^{4}$ Rahmad Amin Angkat, ${ }^{5}$ Eni Ery Yanti \\ $1,2,3,4,5$ Universitas Islam Sumatera Utara \\ 1roni.mukti@gmail.com, ${ }^{2}$ leonard.simorangkir@gmail.com, ${ }^{3}$ satria.ginting@gmail.com, \\ ${ }^{4}$ rahmad.amin@gmail.com, ${ }^{5}$ eniery.yanti@gmail.com
}

\begin{abstract}
The Formulation In this research is how emotional intelligence influences, job characteristics and workload on the performance of The Education Officer In Padangsidimpuan City, and the purpose of this research is to know and analyze the influence of emotional intelligence, work characteristics and workload on the performance Of The Education Officer Of Padangsidimpuan City. This research is a quantitative descriptive study. Data collection techniques are conducted through interviews, inquiry lists and documentation studies. The samples in this study were as many as 39 employees. Variables are measured at Likert scale. Hypothesis testing using multiple linear regression analyses through F-test and T-Test. The Results of the test in unison showed that emotional intelligence, occupational characteristics and workload demonstrated a very noticeable influence on the performance of The Education Officer In Padangsidimpuan City with the value $F_{\text {count }} 16,464>F_{\text {table }} 2.85$ and significance value of $0.000^{b}$. Adjusted number of $R$ Square by 0. 550 or $(55 \%)$ Show that the percentage of contributions influence independent variables (emotional intelligence, occupational characteristics and workload) to the dependent variables (employee performance) by 55\%. Partially, emotional intelligence was positively influential in the performance of The Education Officer In Padangsidimpuan City with a value of $t_{\text {count }}>t_{\text {table }}(4,444$ $>2,022)$ and a significance value of 0.000. The characteristics of the work positively and significantly affect the performance of The Education Officer In Padangsidimpuan City with the value $T_{\text {count }}>t_{\text {table }}(2,600>2,022)$ and the significance value of 0.014 . The workload was negatively and significantly influential on the performance of The Education Officer In Padangsidimpuan City with a value of $t_{\text {count }}<t_{\text {table }}(-3,287<2,022)$ and a significance value of 0 . 002. The highest value of a regression coefficient is the emotional intelligence $\left(X_{1}\right)$ of 0.497 or 49.7\% and is the most dominant variable affecting the performance of The Education Officer In Padangsidimpuan City.
\end{abstract}

Keywords: Emotional Intelligence, Job Characteristics, Workload, Employee Performance.

ABSTRAK : Rumusan pada penelitian ini adalah bagaimana pengaruh kecerdasan emosional, karakteristik pekerjaan dan beban kerja terhadap kinerja pegawai Dinas Pendidikan Kota Padangsidimpuan, dan tujuan penelitian ini adalah untuk mengetahui dan menganalisis pengaruh kecerdasan emosional, karakteristik pekerjaan dan beban kerja terhadap kinerja pegawai Dinas Pendidikan Kota Padangsidimpuan. Penelitian ini merupakan penelitian deskriptif kuantitatif. Teknik pengumpulan data dilakukan melalui wawancara, daftar pertanyaan dan studi dokumentasi. Sampel dalam penelitian ini sebanyak 39 orang pegawai. Variabel diukur dengan skala Likert. Pengujian hipotesis menggunakan analisis regresi linear berganda melalui uji $F$ dan uji t. Hasil uji secara serempak menunjukkan bahwa kecerdasan emosional, karakteristik pekerjaan dan beban kerja menunjukkan pengaruh sangat nyata terhadap kinerja pegawai Dinas Pendidikan Kota Padangsidimpuan dengan nilai $F_{\text {hitung }} 16.464>F_{\text {tabel }} 2.85$ dan nilai signifikansi sebesar $0.000^{b}$. Angka Adjusted $R$ Square sebesar 0.550 atau (55\%) menunjukkan bahwa persentase sumbangan pengaruh variabel independen (kecerdasan emosional, karakteristik pekerjaan dan beban kerja) terhadap variabel dependen (kinerja pegawai) sebesar 55\%. Secara parsial, Kecerdasan Emosional berpengaruh positif terhadap kinerja pegawai Dinas Pendidikan Kota Padangsidimpuan dengan nilai $t_{\text {hitung }}>t_{\text {tabel }}(4.444>2.022)$ dan nilai signifikansi sebesar 
0.000. Karakteristik Pekerjaan berpengaruh positif dan signifikan terhadap kinerja pegawai Dinas Pendidikan Kota Padangsidimpuan dengan nilai $t_{\text {hitung }}>t_{\text {tabel }}(2.600>2.022)$ dan nilai signifikansi sebesar 0.014. Beban kerja berpengaruh negatif dan signifikan terhadap kinerja pegawai Dinas Pendidikan Kota Padangsidimpuan dengan nilai $t_{\text {hitung }}<t_{\text {tabel }}(-3.287<2.022)$ dan nilai signifikansi sebesar 0.002. Nilai koefisien regresi yang paling tinggi adalah Kecerdasan Emosional $\left(X_{1}\right)$ sebesar 0.497 atau 49,7\% dan merupakan variabel yang paling dominan mempengaruhi kinerja pegawai Dinas Pendidikan Kota Padangsidimpuan.

Kata kunci: Kecerdasan Emosional, Karakteristik Pekerjaan, Beban kerja, Kinerja Pegawai.

\section{Pendahuluan}

Dinas

Pendidikan

Kota

Padangsidimpuansalah satu sumberdaya organisasi yang mempunyai nilai prakarsa dan memiliki peran penting dalam pemberdayaan sumberdaya lainnya di dalam organisasi. Sistem pengelolaan Sumber Daya Manusia (SDM) yang tepat merupakan kunci keberhasilan organisasi untuk mencapai tujuannya. Oleh karena itu, agar tujuan dan sasaran organisasi dapat dicapai, perlu adanya perhatian yang lebih dari organisasi terhadap upaya-upaya dalam meningkatkan kinerja pegawai.

Selanjutnya menurut Siagian (2008:77), menyatakan melalui komunikasi para anggota organisasi akan mengerti dan memahami apa yang diinginkan oleh organisasi dimana mereka bernaung, dan sebaliknya organisasi juga akan mengerti dan memahami apa yang diharapkan para anggota organisasi sehingga mempermudah organisasi dalam mencapai tujuannya. Sejalan dengan itu pemerintah telah mengeluarkan beberapa regulasi yang berhubungan dengan pelaksanaan fungsi pelayanan pemerintah dalam mendorong pelayanan publik yang prima, seperti Surat Keputusan Menpan No. 81/1993 Tentang Peningkatan Pelayanan Publik, Instruksi Presiden No. 1/1995 tentang Peningkatan Mutu Pelayanan Bagi Masyarakat dan Surat Keputusan Menteri Pendayagunaan Aparatur Negara No. 63/KEP/7/M.PAN/2003 Tentang Pedoman Umum Penyelenggaraan Pelayanan Publik.

Meskipun telah banyak peraturan dan regulasi yang dikeluarkan pemerintah dalam mendorong terciptanya pelayanan publik yang prima, namun secara umum kinerja pelayanan publik yang dihasilkan oleh organisasi publik di Indonesia relatif belum prima dan belum mencapai tujuan yang diharapkan. Kenyataan empirik membuktikan bahwa pelayanan publik yang diberikan pihak pemerintah maupun swasta saat ini terutama di Indonesia masih bersifat minta dilayani (to be served), sehingga banyak menimbulkan ketidakpuasan masyarakat tentang pelayanan yang diberikan

Pentingnya kinerja pegawai dalam melaksanakan program kerja Dinas Pendidikan Kota Padangsidimpuansemakin dirasakan.Menurut Rivai (2009:88) menjelaskan kinerja adalah perilaku nyata yang diperlihatkan oleh pegawai sebagai prestasi kerja yang dihasilkan sesuai dengan peranannya dalam organisasi.Dengan demikian dapat dikatakan bahwa kinerja adalah prestasi kerja seseorang, baik secara kuantitas maupun secara kualitas.

Penelitian yang berkaitan dengan kinerja pegawai telah banyak dilakukan oleh para peneliti terdahulu. Berdasarkan hasil penelusuran studi empiris diatas, faktoryang teridentifikasi mempengaruhi kinerja pegawai Dinas Pendidikan Kota Padangsidimpuanadalah beban kerja.Secara umum,istilah bebankerja mengacupada jumlah pekerjaanyangdialokasikan kepada pegawai untukdiselesaikan. Sementara Hasibuan(2008:88) mendefinisikanbeban kerjasebagaijumlahpekerjaanyang harus diselesaikan oleh sekelompokatau seseorang dalamwaktutertentu.Bebankerja seseorang menurutMangkunegara (2009:77) sudah ditentukan dalambentukstandar kerja organisasi menurutjenispekerjaannya.Lebih

lanjut,Mangkunegara

mengemukakanbebankerjayang dibebankan kepada pegawaidapatterjadidalamtiga kondisi,yaitu:Pertama,bebankerja sesuai standar. Kedua, bebankerja yang terlalu tinggi (overcapacity).Ketiga, beban kerja yangterlalu rendah (under capacity).

Bebankerja pegawai Dinas Pendidikan Kota Padangsidimpuan adalah besaran pekerjaan yang harus dikerjakan oleh pegawai dan merupakan hasil kali antara jumlah pekerjaan dengan waktu. Melihat pada visi, misi, tugas pokok dan fungsi Dinas Pendidikan Kota Padangsidimpuan maka dapat dilihat fenomena bahwa dalam pengelolaan organisasi memiliki tantangan yang cukup berat. 
Sehingga dengan kondisi tersebut diperlukan kinerja pegawai yang dapat memenuhi tujuan organisasi.Setelah melakukan observasi awal pada Dinas Pendidikan Kota Padangsidimpuan dapat diperoleh gambaran kondisi nyata mengenai beban kerja pegawai diantaranya secara psikologis ada sebagian pegawai Nampak mengalami kelelahan fisik maupun non fisik akibat beratnya beban kerja sehingga kondisi ini memberikan dampak pada keadaan mental dan psikologis pegawai yang cenderung melemah sebagai akibat dari beban kerja yang berat hingga diperlukan dorongan dari atasan agar beban kerja tersebut tidak sampai melemahkan semangat kerja pegawai.

Hal ini menyebabkan masalah beban kerja menarik untuk dikaji secara lebih mendalam pada Dinas Pendidikan Kota Padangsidimpuan, dimana kondisi ini menjadi sebuah fenomena yang mengakibatkan beban kerja tidak sepenuhnya mampu mendorong kinerja pegawai dalam melaksanakan tugas.Untuk mengungkap fenomena penelitian yang berkaitan dengan beban kerja pegawai Dinas Pendidikan Kota Padangsidimpuan, maka penulis merujuk pada teori Sink (2009:129) menyatakan ukuran beban kerjayang dihubungkan dengan performasnce (kinerja) diantaranya adalah beban waktu(time load), beban usaha mental (mental effort load) dan beban tekanan psikologis (psychological stress load).

Faktor lain yang dapat mempengaruhi kinerja pegawai Dinas Pendidikan Kota Padangsidimpuan adalah karakteristik pekerjaan.Menurut Samsuddin (2009:55), karakteristik pekerjaan adalah upaya mengidentifikasikan karakteristik tugas dari pekerjaan, bagaimana karakteristik itu digabung untuk membentuk pekerjaan yang berbeda dan hubungannya dengan kinerja pegawai. Model

karakteristik pekerjaan (job characteristic models) merupakan suatu pendekatan terhadap pemerkayaan pekerjaan (job enrichment). Program pemerkayaan pekerjaan berusaha merancang pekerjaan dengan cara membantu para pemangku jabatan memuasakan kebutuhan mereka akan pertumbuhan, pengakuan, dan tanggung jawab. Pemerkayaan pekerjaan menambahkan sumber kepuasan kepada pekerjaan.Metode ini meningkatkan tanggung jawab, otonomi, dan kendali. Fenomena yang terjadi tentang karakteristik pekerjaan Dinas Pendidikan Kota Padangsidimpuan, antara lain tanggung jawab pegawai terhadap tugas yang diembannya masih belum optimal. Hal ini dapat dilihat masih ada pegawai yang bekerja belum sesuai dengan beban dan tanggungjawab yang diembannya.

Faktor berikutnya yangteridentifikasi mempengaruhi kinerja pegawai Dinas Pendidikan Kota Padangsidimpuanadalah kecerdasan emosional. Menurut Goleman (2009:88), kecerdasan emosional adalah kemampuan untuk mengenali emosi diri, mengelola emosi, mengenali emosi orang lain, dan membina hubungan dengan orang lain. Dengan demikian dapat disimpulkan bahwa seorang pegawai yang memiliki kecerdasan emosional yang tinggi (berkaitan dengan kemampuan mengenali emosi diri, mengelola emosi, mengenali emosi orang lain, dan membina hubungan dengan orang lain) maka pegawai tersebut cenderung memiliki kinerja yang tinggi dalam melaksanakan pekerjaannya. Untuk mengungkap fenomena kecerdasan emosional pegawai Dinas Pendidikan Kota Padangsidimpuan, peneliti melakukan survey awal terhadap 10 orang pegawai Dinas Pendidikan Kota Padangsidimpuan dimana hasil survey tersebut disajikan pada tabel berikut:

Tabel 1. Hasil survey awal kecerdasan emosional

\begin{tabular}{|c|c|c|c|c|}
\hline No & \multicolumn{1}{|c|}{ Uraian } & $\begin{array}{c}\text { Jumlah } \\
\text { Pengamatan } \\
\text { (Orang) }\end{array}$ & Ya & Tidak \\
\hline 1 & $\begin{array}{l}\text { Ketika anda diperolok-olokan oleh teman, } \\
\text { anda selalu bisa bersabar dengan tidak } \\
\text { membalasnya }\end{array}$ & 15 & 5 & 10 \\
\hline 2 & $\begin{array}{l}\text { Anda dapat dengan mudah memahami } \\
\text { perasaan orang lain (rekan kerja) }\end{array}$ & 15 & 6 & 9 \\
\hline
\end{tabular}

Sumber: Survei Awal, 2020

Dari Tabel 1, dapat dilihat bahwa kebanyakan pegawai (10 orang) belum bisa bersikap sabar ketika menerima olok-olokan dari rekan kerja, sementara sebanyak 9 orang pegawai menyatakan bahwa mereka belum dapat memahami perasaan orang lain (rekan kerja), sehingga situasi ini dapat dikatakan bahwa kecerdasan emosional pegawai Dinas 
Pendidikan Kota Padangsidimpuan masih perlu mendapat perhatian

\subsection{Batasan Masalah}

Berdasarkan uraian di atas, banyak faktor yang berpengaruh pada variabel kinerja pegawaiDinas Pendidikan Kota Padangsidimpuan, sehingga dalam penelitian ini peneliti membatasi kepada variabel independen yaitukecerdasan emosional, karakteristik pekerjaan dan beban kerja.

\subsection{Hioptesis}

Berdasarkan uraian teoritis dan kerangka konseptual serta studi empiris di atas, maka dapat ditarik hipotesis penelitian ini sebagai berikut :

1) Kecerdasan emosional berpengaruh terhadap kinerja pegawai Dinas Pendidikan Kota Padangsidimpuan.

2) Karakteristik pekerjaan berpengaruh terhadap kinerja pegawai Dinas Pendidikan Kota Padangsidimpuan.

3) Beban kerja berpengaruh terhadap kinerja pegawai Dinas Pendidikan Kota Padangsidimpuan.

4) Kecerdasan emosional, karakteristik pekerjaan dan beban kerja berpengaruh terhadap kinerja pegawai Dinas Pendidikan Kota Padangsidimpuan.

\subsection{Tujuan Penelitian}

Tujuan dari penelitian ini adalah :

1) Untuk mengetahui dan menganalisispengaruh kecerdasan emosional terhadap kinerja pegawai Dinas Pendidikan Kota Padangsidimpuan.

2) Untuk mengetahui menganalisispengaruh karakteristik pekerjaan terhadap kinerja pegawai Dinas Pendidikan Kota Padangsidimpuan.

3) Untuk mengetahui dan menganalisispengaruh beban kerja terhadap kinerja pegawai Dinas Pendidikan Kota Padangsidimpuan.

4) Untuk mengetahui dan menganalisispengaruh kecerdasan emosional, karakteristik pekerjaan dan beban kerja terhadap kinerja pegawai Dinas Pendidikan Kota Padangsidimpuan.

\section{Metode Penelitian}

\subsection{Populasi}

Menurut Sugiyono (2009:90) populasi adalah wilayah generasi yang terdiri dari atas objek/subjek yang mempunyai kualitas karakteristik tertentu yang disajikan oleh peneliti untuk dipelajari dan kemudian ditarik kesimpulannya. Berdasarkan defenisi tersebut, maka populasi dalam penelitian ini adalahpara pegawai Dinas Pendidikan Kota Padangsidimpuanyang berjumlah 39 orang.

\subsection{Sampel}

Menurut Sugiyono (2009:93), sampel adalah elemen-elemen populasi yang dipilih atas dasar kemampuan mewakilinya. Untuk menjadi pedoman jika subjeknya atau populasinya kurang dari 100, maka lebih baik diambil semua sebagai sampel, sehingga penelitiannya merupakan penelitian populasi.Selanjutnya jika jumlah subjeknya atau populasinya besar atau lebih dari 100, maka dapat diambil persentasenya.Dengan teknik penarikan sampel secara total sampling, maka sampel dalam penelitian ini seluruh populasi yaitu 39 orang pegawai Dinas Pendidikan Kota Padangsidimpuan.

Tabel 2. Distribusi Sampel Penelitian Berdasarkan Bagian

\begin{tabular}{|c|l|c|}
\hline No & \multicolumn{1}{|c|}{ Keterangan } & Jumlah (Orang) \\
\hline 1 & Sekretariat & 18 \\
\hline 2 & Bidang Pembinaan PAUN dan PNF & 5 \\
\hline 3 & Bidang Pembinaan Pendidikan Dasar & 11 \\
\hline 4 & Bidang Pembinaan Ketenagaan & 5 \\
\hline \multicolumn{2}{|c|}{ Total } & 39 \\
\hline
\end{tabular}

Sumber :Dinas Pendidikan Kota Padangsidimpuan, 2020

\subsection{Uji Normalitas}

Uji normalitas bertujuan untuk menguji apakah dalam model regresi variabel pengganggu (residual) memiliki distribusi normal. Seperti diketahui bahwa uji " $t$ " dan uji
F mengasumsikan bahwa nilai residual mengikuti distribusi normal.

Dalam penelitian ini pengujian normalitas dideteksi melalui analisa grafik P-P Plot.yang dihasilkan melalui SPSS. Adapun output grafik 
P-P Plot seperti terlihat pada gambar dibawah ini:

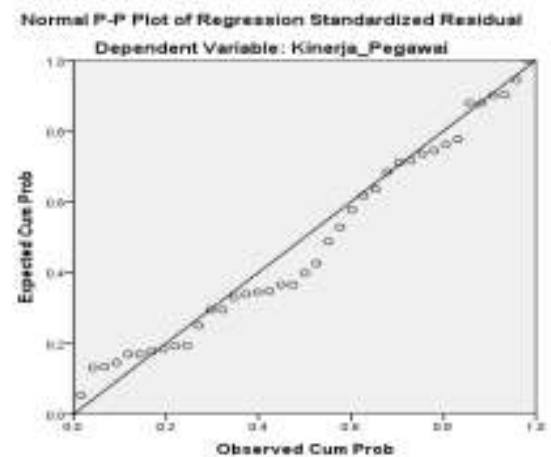

Gambar 1. Uji normalitas P-P Plot Test

Berdasarkan gambar $1 \mathrm{di}$ atas, terlihat bahwa distribusi dari titik-titik data kecerdasan emosional, karakteristik pekerjaan, beban kerja dan kinerja menyebar. Grafik P-P Plot diatas menunjukan bahwa sebaran data menyebar disekitar garis diagonal, sehingga asumsi normalitas dipenuhi. Maka model regresi layak dipakai untuk memprediksi kinerja berdasarkan variabel independennya.

Berdasarkan gambar 2 dibawah terlihat bahwa grafik histogram memberikan pola distribusi normal tidak berpola distribusi melenceng (swewness) ke kiri atau ke kanan, maka model regresi memenuhi asumsi normalitas.

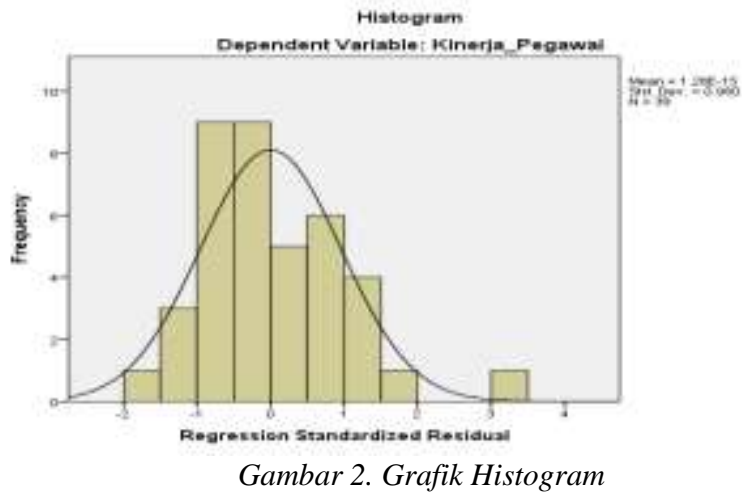

\subsection{Uji Multikolinearitas}

Metode untuk menguji ada tidaknya multikolinearitas dapat dilihat Tolerance Value dan Inflation Factor (VIF). Batas tolerance value adalah 0,10 atau nilai VIF adalah 10. Jika tolerance value $>0,10$ dan VIF $<10$ maka tidak terjadi multikolinearitas dan sebaliknya jika tolerance value $<0,10$ dan VIF $>10$ maka terjadi multikoleniaritas. Hasil pengolahan dapat dilihat pada tabel 5.14 berikut ini:

Tabel 3. Uji Multikolinearitas

Coefficients $^{\mathrm{a}}$

\begin{tabular}{|rl|r|r|r|r|}
\hline \multirow{2}{*}{ Model } & \multicolumn{2}{|c|}{ Correlations } & \multicolumn{2}{c|}{ Collinearity Statistics } \\
\cline { 3 - 6 } & \multicolumn{1}{|c|}{ Partial } & \multicolumn{1}{c|}{ Part } & \multicolumn{1}{c|}{ Tolerance } & \multicolumn{1}{c|}{ VIF } \\
\hline \multirow{4}{*}{1} & (Constant) & & & & \\
& Kecerdasan_Emosional & .601 & .484 & .947 & 1.056 \\
& Karakteristik_Pekerjaan & .402 & .283 & .815 & 1.227 \\
& Beban_Kerja & -.486 & -.358 & .812 & 1.231 \\
\hline
\end{tabular}

Sumber: Hasil Pengolahan SPSS Tahun 2020

Berdasarkan output table 3 diatas, hasil perhitungan nilai tolerance menunjukan tidak ada variabel independen yang memiliki nilai tolerance kurang dari 0,10 yang berarti tidak ada korelasi antara variabel independen yang nilainya lebih dari $39 \%$. Hasil perhitungan nilai variance inflaction factor (VIF) juga menunjukan hal yang sama, yaitu tidak ada satu variabel independen yang memiliki nilai VIF lebih dari 10. Jadi dapat disimpulkan bahwa tidak ada multikolinieritas antar variabel independen dalam model regresi.

\subsection{Uji Heteroskedastisitas}

Uji heteroskedastisitas dilakukan untuk mengetahui apakah dalam sebuah model regresi terjadi ketidaksamaan varians dari residual suatu pengamatan ke pengamatan lain. Jika varians dari residual dari suatu pengamatan ke pengamatan lain tetap disebut heteroskedastisitas.

Menganalisis data dalam pengujian asumsi klasik ini, peneliti menggunakan Program Statistical Product and Service Solution (SPSS) for Windows dapat dilihat pada gambar 5.3 berikut ini: 


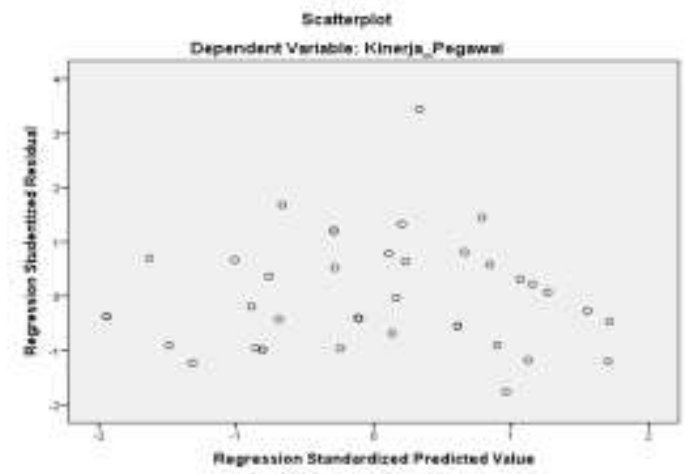

Gambar 3. Grafik scatterplot Uji Heteroskedastisitas

Dari gambar di atas menunjukkan bahwa diagram pencar tidak membentuk suatu pola atau acak, dengan demikian dapat dikatakan bahwa regresi tidak mengalami gangguan heteroskedastisitas pada model regresi sehingga model regresi layak dipakai untuk mengetahui

Tabel 4. Uji Durbin-Watson (DW test) Model Summary $^{b}$

\begin{tabular}{|c|c|c|c|c|}
\hline \multirow[t]{2}{*}{ Model } & \multicolumn{3}{|c|}{ Change Statistics } & \multirow[t]{2}{*}{ Durbin-Watson } \\
\hline & $\mathrm{df1}$ & $\mathrm{df} 2$ & Sig. F Change & \\
\hline 1 & $3^{\mathrm{a}}$ & 35 & .000 & 1.859 \\
\hline
\end{tabular}

Sumber: Hasil Pengolahan SPSS Tahun 2020

Berdasarkan tabel 4 diatas diperoleh nilai Durbin-Watson sebesar 1.859. Nilai DurbinWatson menurut tabel dengan $\mathrm{n}=39$ responden dan $\mathrm{K}=3$ (dalam hal ini adalah jumlah variabel bebas) didapat angka $\mathrm{dl}=1.328 \mathrm{dan} \mathrm{du}=1.657$. Oleh karena itu nilai DW hitung > du (1.859 > 1.657), maka dapat disimpulkan bahwa tidak terdapat autokorelasi dalam model regresi maka model layak untuk digunakan. kinerja pegawai (Y) berdasarkan variabel bebasnya.

\subsection{Uji Autokorelasi}

Uji autokorelasi digunakan untuk melihat hubungan antara variabel bebas memiliki hubungan sama kuat atau tidak, dimana untuk melihat hubungan atau tidak hubungan secara autokorelasi dapat dilihat dengan Uji DurbinWatson (DW test)

Uji Durbin-Watson hanya digunakan untuk autokorelasi tingkat satu (first order autocorrelation) dan mensyaratkan adanya intercept (kostanta) dalam model regresi dan tidak ada variabel lain diantara variabel independent.

\section{Evauasi dan Pembahasan}

\subsection{Analisis Regresi Linier Berganda}

Analisis regresi linier berganda digunakan untuk mengetahui besar pengaruh kecerdasan emosional, karakteristik pekerjaan dan beban kerja terhadap kinerja pegawai Kantor Dinas Pendidikan Kota Padangsidimpuan. Analisis dilakukan dengan menggunakan bantuan SPSS dengan output sebagai berikut:

Tabel 5. Regresi Linear Berganda

Coefficients $^{\mathrm{a}}$

\begin{tabular}{|rl|r|r|r|r|}
\hline Model & \multicolumn{2}{|c|}{ Unstandardized Coefficients } & $\begin{array}{c}\text { Standardized } \\
\text { Coefficients }\end{array}$ & \multirow{2}{*}{$\mathrm{t}$} \\
\cline { 3 - 5 } & \multicolumn{1}{|c|}{$\mathrm{B}$} & Std. Error & \multicolumn{1}{c|}{ Beta } & \\
\hline \multirow{3}{*}{1} & (Constant) & 24.561 & 3.830 & & 6.413 \\
& Kecerdasan_Emosional & .416 & .094 & .497 & 4.444 \\
& Karakteristik_Pekerjaan & .174 & .067 & .313 & 2.600 \\
& Beban_Kerja & -.376 & .114 & -.397 & -3.287 \\
\hline
\end{tabular}

Sumber: Hasil Pengolahan SPSS Tahun 2020

Berdasarkan pengolahan data yang terlihat pada tabel output kolom kedua bagian B (Unstandardized Coefficients), diperoleh persamaan regresi linier berganda yaitu:

$$
y=a+b_{1} x_{1}+b_{2} x_{2}+b_{3} x_{3}+\varepsilon
$$

$\mathbf{Y}=\mathbf{2 4 . 5 6 1}+\mathbf{0 . 4 1 6 X _ { 1 }}+\mathbf{0 . 1 7 4 X _ { 2 }}+\left(-0.376 X_{3}\right)+$
Dengan persamaan regresi linier berganda tersebut dapat dijelaskan bahwa:

1) Nilai konstanta adalah sebesar 24.561 hal ini menyatakan bahwa jika variable kecerdasan emosional, karakteristik pekerjaan dan 
beban kerja diabaikan, maka nilai kinerja pegawai sebesar 24.561.

2) Koefisien regresi untuk variabel kecerdasan emosional sebesar 0.497 hal ini menunjukkan bahwa setiap kenaikan $1 \%$ faktor kecerdasan emosional maka akan meningkatkan kinerja pegawai sebesar $49,7 \%$.

3) Koefisien regresi untuk variabel karakteristik pekerjaan sebesar 0.313 hal ini menunjukkan bahwa setiap kenaikan $1 \%$ faktor karakteristik pekerjaan maka akan meningkatkan kinerja pegawai sebesar $31,3 \%$.
4) Koefisien regresi untuk variable beban kerja sebesar -0.397 hal ini menunjukkan bahwa setiap kenaikan $1 \%$ faktor beban kerja maka akan menurunkan kinerja pegawai sebesar $39,7 \%$.

\subsection{Uji Serempak}

Untuk mengetahui pengaruh kecerdasan emosional, karakteristik pekerjaan dan beban kerja sebagai variabel bebas (X) terhadap kinerja pegawai sebagai variabel terikat $(\mathrm{Y})$ di Kantor Dinas Pendidikan Kota Padangsidimpuan dapat dilihat pada tabel 5.17 berikut.

Tabel 6. Hasil Uji Serempak

ANOVA $^{\mathrm{a}}$

\begin{tabular}{|rl|r|r|r|r|r|}
\hline Model & & Sum of Squares & df & Mean Square & F & Sig. \\
\hline \multirow{3}{*}{1} & Regression & 107.059 & 3 & 35.686 & 16.464 & $.000^{\mathrm{b}}$ \\
& Residual & 75.864 & 35 & 2.168 & & \\
& Total & 182.923 & 38 & & & \\
\hline
\end{tabular}

Sumber: Hasil Pengolahan SPSS Tahun 2020

Dari tabel 6 diatas, diperoleh nilai $F_{\text {hitung }}$ sebesar 16.464. Dengan menggunakan confidence interval (CI) $39 \%$ df $3: 39(\alpha=$ 0.05 ) maka dari tabel distribusi $F$ diperoleh nilai 2.85. Dengan demikian $F_{\text {hitung }} 16.464>F_{\text {tabel }}$ 2.85, maka $\mathrm{H}_{0}$ ditolak dan $\mathrm{H}_{1}$ diterima, artinya variabel kecerdasan emosional, karakteristik pekerjaan serta beban kerja sebagai variabel bebas (X) berpengaruh signifikan terhadap variabel kinerja pegawai di Kantor Dinas Pendidikan Kota Padangsidimpuan.

Pada tabel di atas terlihat nilai signifikansi sebesar $0.000^{\mathrm{b}}$ lebih kecil dari $\alpha=0,05$, hal ini berarti bahwa variabel kecerdasan emosional,

Tabel 7. Hasil Uji Parsial

Coefficients $^{\mathrm{a}}$

\begin{tabular}{|rl|r|r|r|r|}
\hline Model & \multicolumn{2}{|c|}{ Unstandardized Coefficients } & \multicolumn{1}{c|}{$\begin{array}{c}\text { Standardized } \\
\text { Coefficients }\end{array}$} & \\
\cline { 3 - 5 } & & \multicolumn{1}{|c|}{$\mathrm{B}$} & Std. Error & \multicolumn{1}{c|}{ Beta } & \\
\hline \multirow{3}{*}{1} & (Constant) & 24.561 & 3.830 & & 6.413 \\
& Kecerdasan_Emosional & .416 & .094 & .497 & 4.444 \\
& Karakteristik_Pekerjaan & .174 & .067 & .313 & 2.600 \\
& Beban_Kerja & -.376 & .114 & -.397 & -3.287 \\
\hline
\end{tabular}

Dari tabel 7 diatas diperoleh nilai $t_{\text {hitung }}$ masing-masing variabel. Nilai $t_{\text {hitung }}$ tersebut selanjutnya dibandingkan dengan nilai $t_{\text {tabel }}$ pada tingkat kepercayaan $39 \%$ atau $\alpha=0,05$. Nilai $\mathrm{t}_{\text {tabel }}$ pada df 3:39 dengan $\alpha=0,05$ adalah 2.022.

Pengaruh parsial dari variabel kecerdasan emosional $\left(\mathrm{X}_{1}\right)$ diperoleh dengan nilai $\mathrm{t}_{\text {hitung }}$ karakteristik pekerjaan serta beban kerja sebagai variabel bebas memiliki pengaruh yang highly significant. Secara serempak variabel kecerdasan emosional, karakteristik pekerjaan serta beban kerja menunjukkan pengaruh sangat nyata terhadap kinerja pegawai di Kantor Dinas Pendidikan Kota Padangsidimpuan.

\subsection{Uji Parsial}

Uji pengaruh variabel kecerdasan emosional, karakteristik pekerjaan serta beban kerja secara parsial dapat dilihat pada tabel 5.19 berikut: 
apabila kecerdasan emosional $\left(\mathrm{X}_{1}\right)$ meningkat, maka kinerja pegawai Kantor Dinas Pendidikan Kota Padangsidimpuan juga akan meningkat.

Pengaruh parsial dari variabel karakteristik pekerjaan $\left(\mathrm{X}_{2}\right)$ diperoleh dengan nilai $t_{\text {hitung }}$ sebesar 2.600, dengan demikian $t_{\text {hitung }}>t_{\text {tabel }}$ $(2.600>2.022)$ dan nilai signifikan sebesar $0.014<0.05$, maka $\mathrm{H}_{0}$ ditolak dan $\mathrm{H}_{1}$ diterima, yang berarti bahwa variabel karakteristik pekerjaan $\left(\mathrm{X}_{2}\right)$ berpengaruh positif dan signifikan terhadap kinerja pegawai Kantor Dinas Pendidikan Kota Padangsidimpuan. Hal ini berarti bahwa apabila karakteristik pekerjaan $\left(\mathrm{X}_{2}\right)$ meningkat maka kinerja pegawai Kantor Dinas Pendidikan Kota Padangsidimpuan akan meningkat.

Pengaruh parsial dari variabel beban kerja $\left(\mathrm{X}_{3}\right)$ diperoleh dengan nilai $\mathrm{t}_{\text {hitung }}$ sebesar -3.287 , dengan demikian $\mathrm{t}_{\text {hitung }}<\mathrm{t}_{\text {tabel }}(-3.287<2.022)$ dan nilai signifikan sebesar 0. .002 < 0.05 , maka $\mathrm{H}_{0}$ diterima dan $\mathrm{H}_{1}$ ditolak, yang berarti bahwa variabel beban kerja $\left(\mathrm{X}_{3}\right)$ berpengaruh

negatif dan signifikan terhadap kinerja pegawai Kantor Dinas Pendidikan Kota Padangsidimpuan. Hal ini berarti bahwa apabila beban kerja $\left(\mathrm{X}_{3}\right)$ meningkat maka kinerja pegawai Kantor Dinas Pendidikan Kota Padangsidimpuan juga akan menurun.

Berdasarkan hasil analisis diketahui bahwa nilai koefisien regresi yang paling tinggi adalah variabel kecerdasan emosional $\left(\mathrm{X}_{1}\right)$ sebesar 0.497 atau $49,7 \%$. Hal ini berarti bahwa kecerdasan emosional $\left(X_{1}\right)$ berpengaruh lebih dominan terhadap kinerja pegawai Kantor Dinas Pendidikan Kota Padangsidimpuan.

\subsection{Uji Determinasi}

Selanjutnya berdasarkan nilai koefisien determinasi $\left(\mathrm{R}^{2}\right)$ diketahui besarnya pengaruh perubahan variabel kecerdasan emosional, karakteristik pekerjaan serta beban kerja terhadap kinerja pegawai di Kantor Dinas Pendidikan Kota Padangsidimpuan sebagai berikut:

Tabel 8. Koefisien Determinasi

Model Summary ${ }^{b}$

\begin{tabular}{|c|c|c|c|c|c|c|}
\hline \multirow[t]{2}{*}{ Model } & \multirow[t]{2}{*}{$\overline{\mathrm{R}}$} & \multirow[t]{2}{*}{ R Square } & \multirow{2}{*}{$\begin{array}{l}\text { Adjusted R } \\
\text { Square }\end{array}$} & \multirow{2}{*}{$\begin{array}{l}\text { Std. Error of } \\
\text { the Estimate }\end{array}$} & \multicolumn{2}{|c|}{ Change Statistics } \\
\hline & & & & & $\begin{array}{l}\text { R Square } \\
\text { Change }\end{array}$ & F Change \\
\hline 1 & $.765^{\mathrm{a}}$ & .585 & $\overline{.550}$ & $\overline{1.472}$ & .585 & 16.464 \\
\hline
\end{tabular}

Sumber: Hasil Pengolahan SPSS Tahun 2020

Berdasarkan tabel 8 diatas diperoleh angka Adjusted R Square sebesar 0.550 atau (55\%). Hal ini menunjukkan bahwa persentase sumbangan pengaruh variabel independen (kecerdasan emosional, karakteristik pekerjaan serta beban kerja) terhadap variabel dependen (kinerja pegawai) sebesar 55\%. Atau variasi variabel independen yang digunakan dalam model (kecerdasan emosional, karakteristik pekerjaan serta beban kerja) mampu menjelaskan sebesar 55\% variasi variabel dependen (kinerja pegawai). Sedangkan sisanya sebesar $45 \%$ dipengaruhi atau dijelaskan oleh variabel lain yang tidak dimasukkan dalam model penelitian ini.

\section{Kesimpulan}

Dari hasil analisis yang telah dibahas, maka ditarik kesimpulan sebagai berikut:

1) Kecerdasan emosional, karakteristik pekerjaan dan beban kerja menunjukkan pengaruh sangat nyata terhadap kinerja pegawai Kantor Dinas Pendidikan Kota Padangsidimpuan dengan nilai $F_{\text {hitung }} 16.464$
$>\mathrm{F}_{\text {tabel }} 2.85$ dan nilai signifikansi sebesar $0.000^{\mathrm{b}}$.

2) Kecerdasan emosional berpengaruh positif dan signifikan terhadap kinerja pegawai Kantor Dinas Pendidikan Kota Padangsidimpuan dengan nilai $t_{\text {hitung }}>t_{\text {tabel }}$ $(4.444>2.022)$ dan nilai signifikansi sebesar 0.000 .

3) Karakteristik pekerjaan berpengaruh positif dan signifikan terhadap kinerja pegawai Kantor Dinas Pendidikan Kota Padangsidimpuan dengan nilai $t_{\text {hitung }}>t_{\text {tabel }}$ $(2.600>2.022)$ dan nilai signifikansi sebesar 0.014 .

4) Beban kerja berpengaruh negatif dan signifikan terhadap kinerja pegawai Kantor Dinas Pendidikan Kota Padangsidimpuan dengan nilai $\mathrm{t}_{\text {hitung }}<\mathrm{t}_{\text {tabel }}(-3.287<2.022)$ dan nilai signifikansi sebesar 0.002 .

5) Angka Adjusted $R$ Square sebesar 0.550 atau $(55 \%)$ menunjukkan bahwa persentase sumbangan pengaruh variabel independen (kecerdasan emosional, karakteristik 
pekerjaan dan beban kerja) terhadap variabel dependen (kinerja pegawai) sebesar 55\%.

\section{DAFTAR PUSTAKA}

Anoraga, Panji (2014). Psikologi Kerja, PT Rineka Cipta, Jakarta

Arief, C.A., dan Farid, W. (2011). Pengaruh Kecerdasan emosional, Disiplin Kerja dan Kompensasi terhadap Kinerja Pegawai.Jurnal Ekonomi Manajemen Sumber DayaVol. 12, No. 1

Cascio, Wayne F.,( (2009) Managing Human Resources: Productivity, Quality of Work Life, Profits, edition, New York, McGraw Hill

Colquitt, J. A., LePine, J. A., and Wesson., (2009) Organizational Behavior: Improving Performance and Commitment in the Workplace, New York, McGraw Hill, pp. 37

Cross, T.Mdan Lynch.R.R. (2009).Peniliaian dan Evaluasi Kinerja: Konsep dan Praktik. Jakarta. Penerbit Ghalia Indonesia

David, Fred, R. (2008). Manajemen Stratejik: Konsep dan Kasus. Edisi ke 9. Jakarta. Salemba Empat

Dean, J. W., Brandes, P., dan Dharwadkar, R (2008). Organizational cynicism.The Academy of Management Review, 23(2).

Dessler, Gary. (2007). Manajemen Sumber Daya Manusia (Jilid I).Jakarta : Indeks.

Goleman, Daniel. (2009). Emotional Intelligence, Kecerdasan Emosional Mengapa EI Lebih Penting daripada IQ.Jakarta: PT. Gramedia Pustaka Utama.

Hasibuan, Malayu S. P. (2008). Manajemen Sumber Daya Manusia. Edisi Revisi Jakarta: PT. Bumi Aksara.

Mangkunegara, Anwar, Prabu. (2009). Evaluasi Kinerja SDM, Cetakan 4, Bandung : Refika Aditama

Mangkuprawira, Sjafri. (2004). Manajemen Sumber Daya Manusia Strategik. Cetakan ketiga, Penerbit Ghalia Indonesia

Noviansyah dan Zunaidah (2011).Pengaruh Karakteristik Pekerjaan Dan Motivasi Kerja Terhadap Kinerja PegawaiPT. Perkebunan Minanga Ogan Baturaja. Jurnal Manajemen dan Bisnis Sriwijaya Vol.9 No.18.
Ridwan. (2007). Skala Pengukuran VariabelVariabelBandung : Alfabeta

Rivai, Veithzal dan Sagala, Ella Jauvani. (2009). Manajemen Sumber Daya Manusia Untuk Perusahaan : Dari Teori ke Praktek. Jakarta : PT. Rajagrafindo Persada

Robbins S.P dan Judge,T.A. 2007. Perilaku Organisasi. Buku 1 Edisi 12. Terjemahan Diana Angelica. Penerbit Salemba Empat. Jakarta.

Robbins, Stephen P. (2006). Perilaku Organisasi. Edisi kesepuluh. Jakarta: Indeks Kelompok Gramedia.

Rush, Michael dan Althoff, Phillip.(2003). Pengantar Sosiologi Politik.Jakarta: PT. Raja Grafindo Persada.

Samsudin, Sadili. (2009). Manajemen Sumber Daya Manusia. Bandung: CV. Pustaka Setia.

Sedarmayanti. (2004). Good Governance (Kepemerintahan Yang Baik), Bandung : Mandar Maju

Sekaran,U., dan Bougie (2010), Research Methods for Busines. A Skill Building Approach.Fifth Edition.A John Wiley and Sons, Ltd, Publication.

Siagian, Sondang. (2008). Manajemen Sumber Daya Manusia (cetakan 15). Jakarta: Bumi Aksara

Sink, Rdan Tuttle, J.K. (2009). Evaluasi Kinerja. Jakarta: Indeks Kelompok Gramedia.

Sugiyono. (2009). Metode Penelitian Kuantitatif dan Kualitatif dan $R$ dan $D$. Bandung: Alfabeta

Vratskikh, I., Mas'deh, R., Al-Lozi, M., dan Maqbleh, M. (2016). The Impact of Emotional Intelligence on Job Performance via the Mediating Role of Job Satisfaction.International Journal of Business and Management. Vol. 11, No. 2

Yoke, L.B., dan Panatik, S.A. (2016). The Mediatory Role of job Satisfaction between Emotional Intelligence and Job performance. International Business Management Vol 10 No 6. 